\title{
Occurrence of non-native species in a subtropical coastal River, in Southern Brazil
}

\author{
Ocorrência de espécies não-nativas em um rio costeiro subtropical no Sul do Brasil
}

Larissa Faria $^{1^{*}}$ (D), Fabrício de Andrade Frehse ${ }^{1}$ (D), Thiago Vinícius Trento Occhi ${ }^{1}$ (D),

Barbara Maichak de Carvalho ${ }^{1}$ (D), Daniel Vicente Pupo $^{2}$ (D), Sibelle Trevisan Disaró ${ }^{2}$ (D) and Jean Ricardo Simóes Vitule ${ }^{1}$

${ }^{1}$ Laboratório de Ecologia e Conservação - LEC, Universidade Federal do Paraná - UFPR, Campus Centro Politécnico, Setor de Tecnologia, Av. Coronel Francisco Heráclito dos Santos, 100, CEP 81531-980, Curitiba, PR, Brasil

${ }^{2}$ Laboratório de Foraminíferos e Micropaleontologia Ambiental - LaFMA, Universidade Federal do Paraná - UFPR, Campus Centro Politécnico, Setor de Ciências Biológicas, Av. Coronel Francisco Heráclito dos Santos, 100, CEP 81531-980, Curitiba, PR, Brasil

*e-mail: lari.f92@gmail.com

Cite as: Faria, L. et al. Occurrence of non-native species in a subtropical coastal River, in Southern Brazil. Acta Limnologica Brasiliensia, 2021, vol. 33, e101.

Abstract: Aim: This paper aims to concatenate and update the records of non-native species in a subtropical River, in Southern Brazil, warning about their possible impacts in this and other water bodies. Methods: Monitoring was carried out in the Guaraguaçu River, the largest River of the Paraná coastal plain, located in the Atlantic Rainforest biome. Fishes were sampled in two periods: from 2002 to 2007 (monthly) and from 2016 to 2018 (semiannually), and the other organisms were collected in isolated samplings. Results: The monitoring recorded the presence of six nonnative species of animals in this River - four species of fish (Clarias gariepinus, Ictalurus punctatus, Oreochromis niloticus and Salminus brasiliensis), one invertebrate (Macrobrachium rosenbergii) and one foraminifera (Ammoglobigerina globigeriniformis) introduced by escapes from aquaculture, sport fishing and ballast water. These introductions are problematic because they have the potential to impact upon the endangered native species in the River through predation, competition or novel diseases. Conclusions: In Guaraguaçu River the increasing number of introductions is worrying because these species have in common a set of traits that turns them into potential invaders. It is of great importance to keep monitoring their populations in order to detect and minimize their negative impacts on native biota, once there is a conservation unit in the region (Guaraguaçu Ecological Station), with the aim to protect the environment in its pristine condition.

Keywords: agglutinated foraminiferal species; alien species; estuary; ichthyofauna; prawn.

Resumo: Objetivo: Este artigo tem como objetivo reunir e atualizar os registros de espécies nãonativas em um rio subtropical do sul do Brasil, alertando para os impactos que podem exercer neste, e em outros corpos hídricos. Métodos: Foi realizado um monitoramento no rio Guaraguaçu, o maior rio da planície costeira do Paraná, localizado no bioma Mata Atlântica. Os peixes foram amostrados em dois períodos: de 2002 a 2007 (mensalmente) e de 2016 a 2018 (semestralmente), e os demais organismos foram coletados em amostragens isoladas. Resultados: O monitoramento registrou a presença de seis espécies de animais não-nativos neste rio - quatro espécies de peixe (Clarias gariepinus, Ictalurus punctatus, Oreochromis niloticus e Salminus brasiliensis), um invertebrado (Macrobrachium 
rosenbergii) e um foraminífero (Ammoglobigerina globigeriniformis), introduzidos principalmente através de escapes de aquicultura, para pesca esportiva ou por água de lastro. Tais introduçóes são um problema, pois, têm o potencial de impactar negativamente as espécies nativas ameaçadas de extinçáo neste rio através de predação, competição ou introdução de novas doenças. Conclusóes: No rio Guaraguaçu o crescente número de introduçóes é preocupante, pois estas espécies têm em comum um conjunto de características que as tornam potenciais invasoras. Continuar o monitoramento de suas populações é fundamental para detectar e minimizar seus impactos negativos na biota nativa, uma vez que há na região uma unidade de conservação (Estação Ecológica Guaraguaçu), com o objetivo de proteger o ambiente em sua condição prístina.

Palavras-chave: foraminífero aglutinante; espécies exóticas; estuário; ictiofauna; camarão.

The introduction of non-native species is one of the major threats to freshwater ecosystems along with overexploitation, water pollution, flow modification and habitat degradation (Dudgeon et al., 2006). A species is considered non-native when it is introduced outside its original geographic range, usually by human action (Lockwood et al., 2007). When it has a self-sustaining population which is reproducing, it may be considered established and, in some cases, become invasive, for instance causing environmental or economic impacts (Blackburn et al., 2011).

Invasive species are known to cause a great range of negative impacts to biodiversity, in all ecological levels, through new diseases, predation, competition, hybridization and alteration of ecosystems and trophic webs, being one of the leading causes of species extinctions around the world (Clavero \& García-Berthou, 2005; Havel et al., 2015). Freshwater ecosystems, particularly, are even more prone to invasions due to the large number of introduction vectors (e.g. aquaculture, hull fouling, aquarium trade, sport fishing, bait release) (Frehse et al., 2016), and because they are already degraded by human alterations (Bezerra et al., 2019). Because of that, it is of great importance to monitor and record the occurrence of new non-native species in the natural environment, to cope with them before they become invasive, implying ecological impacts and economic losses (Simberloff et al., 2013).

The Guaraguaçu River is the largest River of the Paraná coastal plain, located in the Atlantic Forest biome (Figure 1). The climate in the region is humid subtropical and the River presents a wide variety of habitats that goes from mangroves to a unique ecosystem of backwater locally named "caixetal". It shelters a high level of endemism, with many smallbodied fish species reported in national and regional lists of threatened species (Abilhoa \& Duboc, 2004; Machado et al., 2008). A monitoring initiated in 2002 recorded the presence of six non-native species of animals in this River so far, using different sampling methods (Table 1). Fishes were sampled in two periods: from 2002 to 2007 (monthly) and from 2016 to 2018 (semiannually), and the other organisms were collected in isolated samplings in 2005, 2006 and 2017 (Table 1). This paper aims to concatenate and update these records (e.g. Vitule et al., 2005, 2006, 2014; Pupo \& Disaró, 2006; Gazola-Silva et al., 2007; Eichler et al., 2018) addressing the probable threat that these species may pose to the native biota.

The non-native species found in Guaraguaçu River have in common a set of traits (omnivory, wide environmental tolerance range, high propagule pressure and economic interest) that turns them into potential invaders in many environments or conditions (New et al., 2000; Martin et al., 2010; Gutierre et al., 2014; Weyl et al., 2016). More worrying are the introductions of large predators such as Clarias gariepinus (Burchell, 1822), Ictalurus punctatus (Rafinesque, 1818), and Salminus brasiliensis (Cuvier, 1816) because they have the potential to impact upon the endangered native species in the River through elevated predation pressure (Gubiani et al., 2010; Alexander et al., 2014; Faria et al., 2019). The Nile tilapia Oreochromis niloticus (Linnaeus, 1758) is a highly tolerant species with a short life cycle and omnivorous feeding habits that facilitate its rapid dispersion, being a threat to native species due to competition (Canonico et al., 2005). The introduction of Macrobrachium rosenbergii (De Man, 1879), which is host of two viral diseases responsible for high rates of aquaculture mortality, is also a problem (Bonami \& Sri Widada, 2011).

A species considered an invading foraminifer was the most abundant at Guaraguaçu River in 2005 when it was registered for the first time in Paraná waters, dominating 6 of 23 sampling points, mostly around the mouth and at the lower portion of the River (Figure 2). According to McGann \& Sloan (1999) the agglutinated foraminifer Trochammina hadai Uchio, 1962 first appeared as an invasive species from Japan in estuarine bottom sediments 


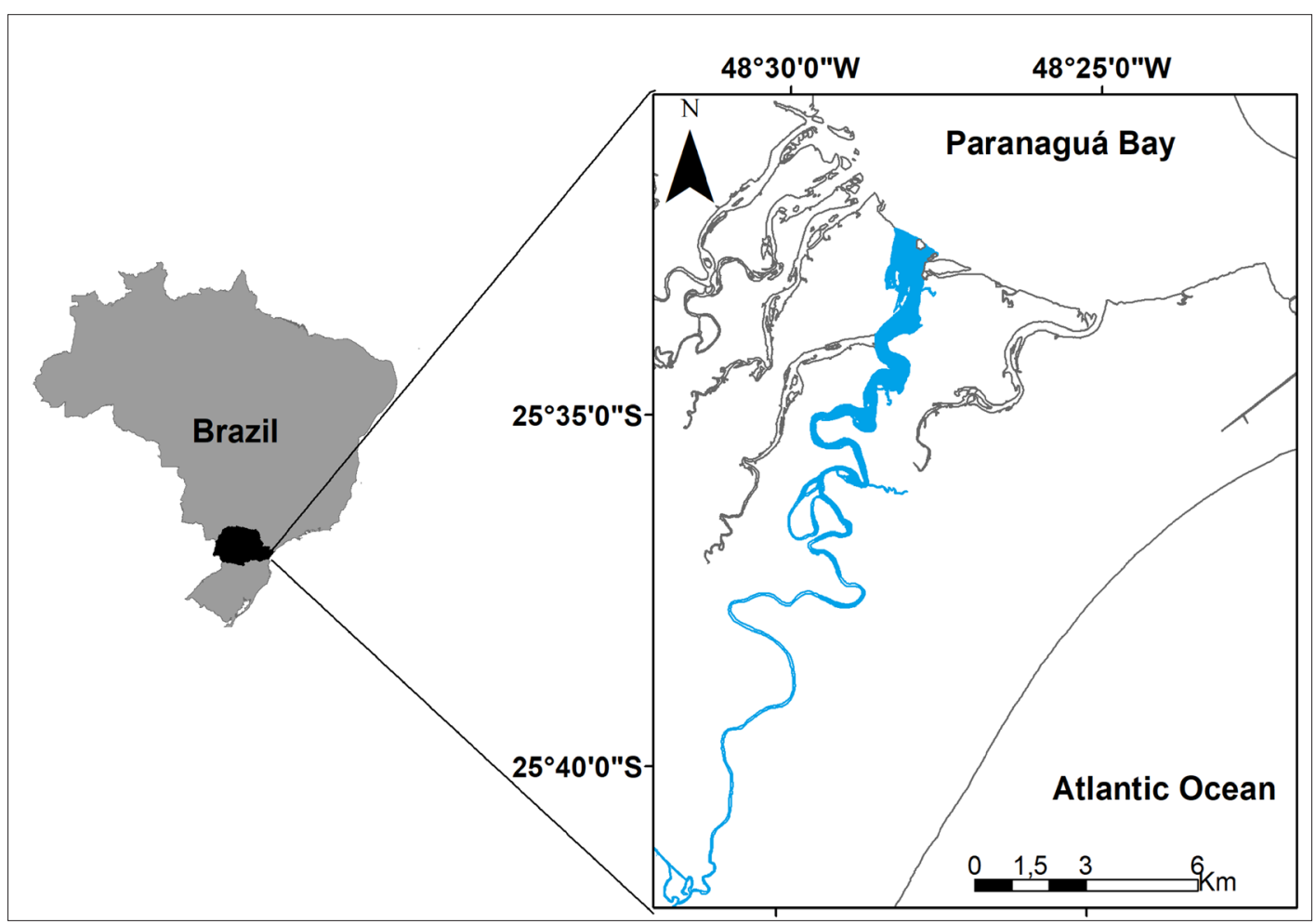

Figure 1. Map of the study area, the Guaraguaçu river in the coastal plain, Paraná State, southern Brazil.

Table 1. Records of non-native species at Guaraguaçu river in the last 18 years.

\begin{tabular}{|c|c|c|c|c|}
\hline Species & Native range & $\begin{array}{l}\text { Year of record } \\
\text { and sampling } \\
\text { method }\end{array}$ & $\begin{array}{l}\text { Possible vector of } \\
\text { introduction }\end{array}$ & Reference \\
\hline $\begin{array}{c}\text { Clarias gariepinus } \\
\text { (Burchell, 1822) }\end{array}$ & $\begin{array}{c}\text { Most of Africa and some parts } \\
\text { of Asia (Israel, Syria and south } \\
\text { of Turkey) }\end{array}$ & $\begin{array}{l}2002 \text { and 2004, gill } \\
\text { net, longline and } \\
\text { fishing rods }\end{array}$ & $\begin{array}{l}\text { Escapes from } \\
\text { aquaculture }\end{array}$ & Vitule et al. (2006) \\
\hline $\begin{array}{l}\text { Ictalurus punctatus } \\
\text { (Rafinesque, 1818) }\end{array}$ & $\begin{array}{c}\text { North America: Central } \\
\text { drainages of the United States } \\
\text { to southern Canada and } \\
\text { northern Mexico }\end{array}$ & $\begin{array}{l}\text { 2004, } 2005 \text { and } \\
\text { 2017, gill net, } \\
\text { longline and fishing } \\
\text { rods }\end{array}$ & $\begin{array}{l}\text { Escapes from } \\
\text { aquaculture }\end{array}$ & Vitule et al. (2005) \\
\hline $\begin{array}{c}\text { Oreochromis } \\
\text { niloticus (Linnaeus, } \\
1758)\end{array}$ & Africa & $\begin{array}{l}2004 \text { to } 2007 \text {, and } \\
2017 \text {, gill net and } \\
\text { cast net }\end{array}$ & $\begin{array}{l}\text { Escapes from } \\
\text { aquaculture }\end{array}$ & This study \\
\hline $\begin{array}{c}\text { Salminus } \\
\text { brasiliensis (Cuvier, } \\
\text { 1816) }\end{array}$ & $\begin{array}{c}\text { Southern South America in } \\
\text { the Paraná, Paraguay and } \\
\text { Uruguay rivers, the Laguna } \\
\text { dos Patos drainage, and the } \\
\text { Chaparé and Mamoré rivers } \\
\text { (Amazon Basin) }\end{array}$ & 2006, gill net & $\begin{array}{l}\text { Deliberate } \\
\text { introduction for } \\
\text { sport fishing }\end{array}$ & Vitule et al. (2014) \\
\hline $\begin{array}{l}\text { Macrobrachium } \\
\text { rosenbergii (De } \\
\text { Man, 1879) }\end{array}$ & Southeast Asia & $\begin{array}{l}\text { Carapace in 2006; } \\
\text { full specimens in } \\
2017, \text { trap }\end{array}$ & $\begin{array}{l}\text { Escapes from } \\
\text { aquaculture }\end{array}$ & $\begin{array}{c}\text { Gazola-Silva et al. } \\
\qquad(2007)\end{array}$ \\
\hline $\begin{array}{c}\text { Ammoglobigerina } \\
\text { globigeriniformis } \\
\text { (Parker \& Jones, } \\
\text { 1865) }\end{array}$ & $\begin{array}{l}\text { North Atlantic, Antarctic, Arctic, } \\
\text { Mediterranean, Red Sea, } \\
\text { Indian Ocean, Abrolhos Bank, } \\
\text { Greenland, South Atlantic from } \\
\quad \sim 55 \text { to } \sim 4000 \text { m depth }\end{array}$ & $\begin{array}{c}\text { Shells with } \\
\text { protoplasm in } \\
\text { 2005; vanVeen } \\
\text { Grab }\end{array}$ & $\begin{array}{c}\text { Ballast water } \\
\text { from transoceanic } \\
\text { tankers and bulk } \\
\text { carrier }\end{array}$ & $\begin{array}{c}\text { Pupo \& } \\
\text { Disaró (2006), } \\
\text { Eichler et al. (2018) }\end{array}$ \\
\hline
\end{tabular}

of San Francisco Bay (California, USA) in 1995. It was registered in 1983 in the same area but, at that time, it comprised a mere $1.5 \%$ of the fauna (McGann, 2014). Eichler et al. (2018) registered T. hadai as an invasive species at Ubatuba (São
Paulo, Brazil) and these authors mentioned its presence at Paranaguá Bay in 2005 based on written information and photos made available by Disaró (personal communication) and Pupo \& Disaró (2006). 


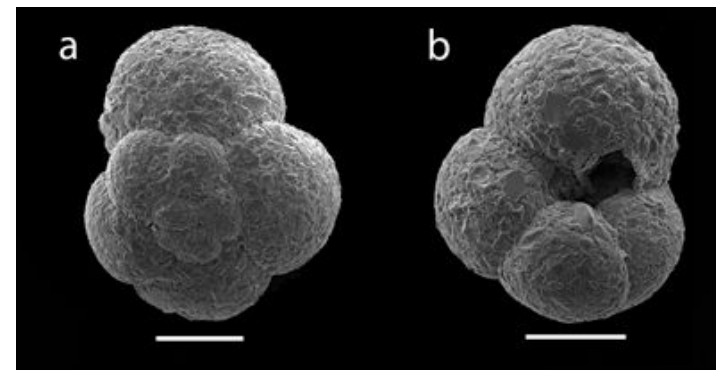

Figure 2. Ammoglobigerina globigeriniformis (Parker \& Jones, 1865). (a) Dorsal view; (b) ventral view. Scale bar: $100 \mu \mathrm{m}$.

This species was assigned to Ammoglobigerina globigeriniformis (Parker \& Jones, 1865) by Pupo and Disaró but, despite the controversial question about its taxonomic identity and origin, the species mentioned by McGann \& Sloan (1999), McGann (2014), Eichler et al. (2018) and Pupo \& Disaró (2006) is, indeed, the same. The mechanism by which it was introduced into the estuarine system is unknown, but it might be related to the release of ballast water, sedimentary residues attached on anchor or cables of transoceanic tankers or bulk carriers at the Paranaguá Port, which is approximately $9 \mathrm{~km}$ from the mouth of the River. Anthropogenic interference may have cooperated with this surprising distribution in an area of the Brazilian coast where this species had never occurred before. Further studies are needed to verify whether this species has established populations that may threaten native species, or if it was just an episodic occurrence.

Aquatic invasions are sometimes hard to detect at early stages, so the effort must be continuous. In Guaraguaçu River the increase of introduction events is worrying because one non-native species can facilitate the establishment of another, elevating their number in the long term, or resulting in trophic cascades and additive or synergistic negative effects on the native community (Ricciardi \& MacIsaac, 2010; Braga et al., 2019). Besides that, the invasion by a few non-native cosmopolite species and the possibly extinction of endemic species caused by them, can lead to biotic homogenization (Rahel, 2002; Ricciardi \& MacIsaac, 2010). The occurrence of these non-native species is also a problem because there is a conservation unit in the region (Guaraguaçu Ecological Station), with the aim to protect the environment in its pristine condition. In order to reach that aim, the presence of non-native species is not acceptable and measures to keep them away are needed. Finally, the varied number of taxa and the constant emergence of new records of occurrence in this basin is an evidence of the intense propagule and colonization pressure in the region.

\section{Acknowledgements}

We are thankful for CAPES (Coordenação de Aperfeiçoamento de Pessoal de Nivel Superior) for the PhD scholarship provided to LF and TVTO; and PNPD CAPES code 001 provided to BMC. We are also thankful to CNPq (Conselho Nacional de Desenvolvimento Científico e Tecnológico) for permanent research grants provided to JRSV (Process Numbers: cont; 303776/2015-3).

\section{References}

ABILHOA, V. and DUBOC, L.F. Peixes. In: S.B. MIKICH and R.S. BÉRNILS, eds. Livro vermelho dos animais ameaçados de extinção no Estado do Paraná. Curitiba: Mater Natura e Instituto Ambiental do Paraná, 2004, pp. 581-677.

ALEXANDER, M.E., DICK, J.T.A., WEYL, O.L.F., ROBINSON, T.B. and RICHARDSON, D.M. Existing and emerging high impact invasive species are characterized by higher functional responses than natives. Biology Letters, 2014, 10(2), 2-6. http://dx.doi.org/10.1098/rsbl.2013.0946. PMid:24522629.

BEZERRA, L.A.V., FREITAS, M.O., DAGA, V.S., OCCHI, T.V.T., FARIA, L., COSTA, A.P.L., PADIAL, A.A., PRODOCIMO, V. and VITULE, J.R.S. A network meta- analysis of threats to South American fish biodiversity. Fish and Fisheries, 2019, 20(4), 620-639. http://dx.doi.org/10.1111/ faf. 12365 .

BLACKBURN, T.M., PYŠEK, P., BACHER, S., CARLTON, J.T., DUNCAN, R.P., JAROŠÍK, V., WILSON, J.R.U. and RICHARDSON, D.M. A proposed unified framework for biological invasions. Trends in Ecology \& Evolution, 2011, 26(7), 333339. http://dx.doi.org/10.1016/j.tree.2011.03.023. PMid:21601306.

BONAMI, J.R. and SRI WIDADA, J. Viral diseases of the giant freshwater prawn Macrobrachium rosenbergii: A review. Journal of Invertebrate Pathology, 2011, 106(1), 131-142. http://dx.doi.org/10.1016/j. jip.2010.09.007. PMid:21215360.

BRAGA, R.R., RIBEIRO, V.M., PADIAL, A.A., THOMAZ, S.M., AFFONSO, I.P., WOJCIECHOWSKI, J., DOS SANTOS RIBAS, L.G., CUNHA, E.R., TIBURCIO, V.G. and VITULE, J.R.S. Invasional meltdown: an experimental test and a framework to distinguish synergistic, additive, and antagonistic effects. Hydrobiologia, 2019, 847(7), 1603-1618. http:// dx.doi.org/10.1007/s10750-019-04107-x. 
CANONICO, G.C., ARTHINGTON, A., MCCRARY, J.K. and THIEME, M.L. The effects of introduced tilapias on native biodiversity. Aquatic Conservation, 2005, 15(5), 463-483. http://dx.doi.org/10.1002/ aqc.699.

CLAVERO, M. and GARCÍA-BERTHOU, E. Invasive species are a leading cause of animal extinctions. Trends in Ecology \& Evolution, 2005, 20(3), 110. http://dx.doi.org/10.1016/j.tree.2005.01.003. PMid: 16701353.

DUDGEON, D., ARTHINGTON, A.H., GESSNER, M.O., KAWABATA, Z.I., KNOWLER, D.J., LÉVÊQUE, C., NAIMAN, R.J., PRIEURRICHARD, A.H., SOTO, D., STIASSNY, M.L.J. and SULLIVAN, C.A. Freshwater biodiversity: importance, threats, status and conservation challenges. Biological Reviews of the Cambridge Philosophical Society, 2006, 81(2), 163-182. http://dx.doi.org/10.1017/S1464793105006950. PMid:16336747.

EICHLER, P.P.B., MCGANN, M., RODRIGUES, A.R., MENDONÇA, A., AMORIN, A., BONETTI, C., FARIAS, C.C., SOUSA, S.H.M., VIDAL, H. and GOMES, M.P. The occurrence of the invasive foraminifera Trochammina hadai Uchio in Flamengo Inlet, Ubatuba, São Paulo State, Brazil. Micropaleontology, 2018, 64, 391-402.

FARIA, L., ALEXANDER, M.E. and VITULE, J.R.S. Assessing the impacts of the introduced channel catfish Ictalurus punctatus using the comparative functional response approach. Fisheries Management and Ecology, 2019, 26(6), 570-577. http://dx.doi. org/10.1111/fme.12353.

FREHSE, F.A., BRAGA, R.R., NOCERA, G.A. and VITULE, J.R.S. Non-native species and invasion biology in a megadiverse country: scientometric analysis and ecological interactions in Brazil. Biological Invasions, 2016, 18(12), 3713-3725. http:// dx.doi.org/10.1007/s10530-016-1260-9.

GAZOLA-SILVA, F.F., MELO, S.G. and VITULE, J.R.S. Macrobrachium rosenbergii (Decapoda: Palaemonidae): possível introduçâo em um rio da planície litorânea paranaense (PR, Brasil). Acta Biológica Paranaense, 2007, 36, 83-90. http://dx.doi. org/10.5380/abpr.v36i0.12295.

GUBIANI, É.A., FRANA, V.A., MACIEL, A.L. and BAUMGARTNER, D. Occurrence of the non-native fish Salminus brasiliensis (Cuvier, 1816), in a global biodiversity ecoregion, Iguaçu River, Paraná River basin, Brazil. Aquatic Invasions, 2010, 5(2), 223-227. http://dx.doi.org/10.3391/ai.2010.5.2.17.

GUTIERRE, S.M.M., VITULE, J.R.S., FREIRE, C.A. and PRODOCIMO, V. Physiological tools to predict invasiveness and spread via estuarine bridges: tolerance of Brazilian native and worldwide introduced freshwater fishes to increased salinity.
Marine and Freshwater Research, 2014, 65(5), 425436. http://dx.doi.org/10.1071/MF13161.

HAVEL, J.E., KOVALENKO, K.E., THOMAZ, S.M., AMALFITANO, S. and KATS, L.B. Aquatic invasive species: challenges for the future. Hydrobiologia, 2015, 750(1), 147-170. http://dx.doi.org/10.1007/ s10750-014-2166-0. PMid:32214452.

LOCKWOOD, J.L., HOOPES, M. and MARCHETTI, M. Invasion ecology. Oxford: Blackwell Publishing, 2007.

MACHADO, A.B.M., DRUMMOND, G.M. and PAGLIA, A.P. Livro Vermelho da Fauna Brasileira Ameaçada de Extinção. Belo Horizonte: Fundação Biodiversitas, 2008.

MARTIN, C.W., VALENTINE, M.M. and VALENTINE, J.F. Competitive interactions between invasive Nile Tilapia and native fish: the potential for altered trophic exchange and modification of food webs. PLoS One, 2010, 5(12), e14395. http://dx.doi.org/10.1371/journal.pone.0014395. PMid:21200433.

MCGANN, M. and SLOAN, D. Benthic foraminifers in the Regional Monitoring Program's San Francisco Estuary samples. In: Proceedings of the 1997 Annual Report for the Regional Monitoring Program for Trace Substances in the San Francisco Estuary. Richmond: San Francisco Estuary Institute, 1999, pp. 249-258.

MCGANN, M. Earliest record of the invasive Foraminifera Trochammina hadai in San Francisco Bay, California, USA. Marine Biodiversity Records, 2014, 7(e94), 1-7. http://dx.doi.org/10.1017/ S1755267214000888.

NEW, M.B., D'ABRAMO, L.R., VALENTI, W.C. and SINGHOLKA, S. Sustainability of freshwater prawn culture. In: M.B. NEW and W.C. VALENTI, eds. Freshwater prawn culture: the farming of Macrobrachium rosenbergii. Oxford: Blackwell Science, 2000, pp. 429-434. http://dx.doi. org/10.1002/9780470999554.ch23.

PUPO, D.V. and DISARÓ, S.T. Characterization of Guaraguaçú River (Paraná, Brazil) based on the distribution of foraminiferal and thecamoebian assemblages and sedimentological analysis. Anuário do Instituto de Geociências, 2006, vol. 29, no. 1, pp. 434-435.

RAHEL, F.J. Homogenization of freshwater faunas. Annual Review of Ecology and Systematics, 2002, 33(1), 291-315. https://doi.org/DOI 10.1146/ annurev.ecolysis.33.010802.150429. http://dx.doi. org/10.1146/annurev.ecolsys.33.010802.150429.

RICCIARDI, A. and MACISAAC, H.J. Impacts of biological invasions on freshwater ecosystems. In: D.M. RICHARDSON, ed. Fifty years of invasion ecology: the legacy of Charles Elton. Chichester: John Wiley \& Sons, 2010, pp. 211-224. http://dx.doi. org/10.1002/9781444329988.ch16. 
SIMBERLOFF, D., MARTIN, J.L., GENOVESI, P., MARIS, V., WARDLE, D.A., ARONSON, J., COURCHAMP, F., GALIL, B., GARCÍA-BERTHOU, E., PASCAL, M., PYŠEK, P., SOUSA, R., TABACCHI, E. and VILÀ, M. Impacts of biological invasions: what's what and the way forward. Trends in Ecology \& Evolution, 2013, 28(1), 58-66. http://dx.doi.org/10.1016/j. tree.2012.07.013. PMid:22889499.

VITULE, J.R.S., UMBRIA, S.C. and ARANHA, J.M.R. Registro de ocorrência do Bagre do Canal Ictalurus punctatus (Rafinesque, 1818) em uma importante bacia hidrográfica da Floresta Atlântica Paranaense. In: Anais do I Simpósio Brasileiro sobre Espécies Exóticas Invasoras. Brasília: Ministério do Meio Ambiente, 2005.

VITULE, J.R.S., UMBRIA, S.C. and ARANHA, J.M.R. Introduction of the African catfish Clarias gariepinus (BURCHELL, 1822) into Southern Brazil. Biological Invasions, 2006, 8(4), 677-681. http://dx.doi. org/10.1007/s10530-005-2535-8.
VITULE, J.R.S., BORNATOWSKI, H., FREIRE, C.A. and ABILHOA, V. Extralimital introductions of Salminus brasiliensis (Cuvier, 1816) (Teleostei, Characidae) for sport fishing purposes: a growing challenge for the conservation of biodiversity in neotropical aquatic ecosystems. BioInvasions Records, 2014, 3(4), 291-296. http://dx.doi.org/10.3391/bir.2014.3.4.11.

WEYL, O.L.F., DAGA, V.S., ELLENDER, B.R. and VITULE, J.R.S. A review of Clarias gariepinus invasions in Brazil and South Africa. Journal of Fish Biology, 2016, 89(1), 386-402. http://dx.doi.org/10.1111/jfb.12958. PMid:27094809.

Received: 24 March 2020

Accepted: 04 July 2020

Associate Editor: Luiz Ubiratan Hepp. 